Розділ І. Ціннісні орієнтири духовно-інтелектуального виховання, розвиток духовно-інтелектуальних якостей особистості в умовах співпраці й інклюзії

\title{
САМООСВІТНЯ КОМПЕТЕНТНІСТЬ ШКОЛЯРІВ: СУТНІСТЬ ТА СТРУКТУРА
}

\section{Пономарьова Н. О.}

доктор педагогічних наук, професор, декан фізико-математичного факультету, Харківський національний педагогічний університет імені Г. С. Сковороди, м. Харків, Україна

\section{Майстрюк I. C.}

здобувач третього (освітньо-наукового) рівня вищої освіти,

Харківський національний педагогічний університет імені Г. С. Сковороди, м. Харків, Україна

У статті обгрунтовано значущість вивчення поняття «самоосвітня компетентність» з огляду на нагальну проблему формування у школярів здатності до навчання впродовж життя. Розкрито зв 'язок поняття самоосвітньої компетентності із саморозвитком та самоосвітою. Проаналізовано сутність та структуру самоосвітньої компетентності.

Ключові слова: навчання впродовж життя, самоосвіта, саморозвиток, самоосвітня компетентність.

The article substantiates the importance of studying the concept of "self-educational competence» in view of the urgent problem of forming students' ability to learn throughout life. The connection of the concept of self-educational competence with self-development and self-education is revealed. The essence and structure of self-educational competence are analyzed.

Key words: lifelong learning, self-education, self-development, self-educational competence.

На сьогоднішній день освіта зазнає значних змін та реформ. Цей процес спрямований, зокрема на те, щоб сформувати у випускників закладів загальної середньої освіти здатність самостійно навчатися впродовж усього життя. У концепції Нової української школи зазначається, що ключовою компетентністю особистості є здатність до пошуку та засвоєння нових знань, набуття нових вмінь і навичок, організації навчального процесу (власного і колективного), зокрема через ефективне керування ресурсами та інформаційними потоками, вміння визначати навчальні цілі та способи їх досягнення, вибудовувати свою 
освітньо-професійну траєкторію, оцінювати власні результати навчання [1]. Державний стандарт базової середньої освіти до ключових компетентностей відносить навчання впродовж життя - здатність визначати і оцінювати власні потреби та ресурси для розвитку компетентностей, застосовувати різні способи розвитку компетентностей, знаходити можливості для навчання і саморозвитку; спроможність навчатися і працювати в колективі та самостійно, організовувати своє навчання, оцінювати його, ділитися його результатами з іншими, шукати підтримки, коли вона потрібна [2].

Уміння навчатися впродовж життя закладається у самоосвітній діяльності школярів, що є складним процесом, під час якого вони самостійно ставлять перед собою пізнавальну мету і завдання, визначають шляхи їх досягнення, контролюють хід самостійної роботи з надбання знань і вдосконалюють результати. І ця діяльність вимагає сформованості й самоосвітньої компетентності [3].

Аналіз психолого-педагогічної літератури у цьому ракурсі засвідчив актуальність та багатогранність питання формування самоосвітньої компетентності. У розрізі педагогічної проблематики іiі досліджували С. Архангельський, В. Буряк, П. Гальперін, А. Громцева, Т. Землінська, Ю. Калугін, О. Кисельова, І. Преображенська, Б. Райський, Н. Терещенко, О. Фоміна та ін., з точки зору психології - Б. Ананьєв, Л. Виготський, Г. Костюк, О. Леонтьєв та ін. Філософські аспекти проблеми вивчали О. Бурлука, Б. Гершунський та ін. Н. Бабкова-Пилипенко, Л. Дибкова, І. Грабовець, О. Набока, Л. Скібицька, О. Шукліна та ін. зосереджувалися на соціологічному вивченні проблеми. Щодо зарубіжних досліджень проблем самоосвіти, то основна уваги учених переважно зосереджується на формуванні готовності особистості вчитися протягом життя (наприклад, N. Eliason, G. Gill, N. Halim, G. Petty та ін. досліджують проблеми методів самонавчання).

Дійсно, поняття самоосвітньої компетентності школярів тісно пов'язане із поняттями «саморозвиток» та «самоосвіта».

Саморозвиток - це усвідомлений і керований особистістю процес, у результаті якого відбувається удосконалення фізичних, розумових і моральних потенцій людини, розгортання її індивідуальності [4].

Самоосвіта у психолого-педагогічних дослідженнях розглядається як цілеспрямована та самостійна пізнавальна діяльність для задоволення інтересів, потреб людини в пізнанні оточуючого світу. У само- 
Розділ І. Ціннісні орієнтири духовно-інтелектуального виховання, розвиток духовно-інтелектуальних якостей особистості в умовах співпраці й інклюзії

освіті людина сама ставить перед собою пізнавальні цілі й завдання, визначає шляхи їх досягнення, контролює хід самостійної роботи щодо набуття знань, оцінює її результати [5].

Самоосвітня компетентність визначається вченими як інтегративна якість особистості, що проявляється у здатності до цілеспрямованої, самостійно організованої освітньої діяльності, а також у наявності певного комплексу знань, умінь, навичок та особистісно-професійного досвіду [6].

Самоосвітня компетентність — це інтегрована характеристика особистості, яка містить у собі знання, уміння, навички та досвід самоосвіти, особистісні якості, які проявляються у потребі, здатності та готовності до реалізації певного виду діяльності, спрямованої на досягнення особистісної, професійної та соціальної самореалізації людини, характеризується особистісними та професійними цінностями, які зумовлюють готовність і здатність особистості успішно здійснювати самоосвітню діяльність [7].

Самоосвітня компетентність учнів закладів загальної середньої освіти являє собою інтегровану якість, що визначається певним чином організованими і систематизованими знаннями, самоосвітніми вміннями та навичками, чіткими мотивами діяльності, зацікавленістю в якісній самостійній діяльності, прагненням до самовдосконалення, формуванням ціннісних орієнтацій, що дозволять успішно вирішувати питання самореалізації та саморозвитку, спрямованістю на здобуття освіти впродовж життя [8].

Аналіз психолого-педагогічних досліджень засвідчує, що вчені виділяють у структурі самоосвітньої компетентності такі взаємозалежні та взаємообумовлені компоненти, як мотиваційно-ціннісний, практично-діяльнісний, організаційний та особистісно-рефлексивний, при чому у кожному з компонентів вагоме місце займає володіння сучасними інструментами здійснення самоосвітньої діяльності.

Так, наприклад, В. Коваленко у структурі самоосвітньої компетентності виокремлює такі структурні компоненти: мотиваційно-ціннісний (активність, прагнення, усвідомлена особистісна настанова, ціннісна орієнтація на самовдосконалення в інтелектуальній сфері); організаційний (побудова самоосвітньої діяльності, цілеспрямованість, сконцентрованість, самокерування, саморефлексія у пізнавальній діяльності); процесуальний (самокерування рухом від пізнавальної мети 
до результату засобами самостійно організованої пізнавальної дальності, функціональність знань, умінь і навичок, їх самостійне вдосконалення); та як окремий складник - інформаційний (здатність і готовність працювати з інформацією, сучасними інформаційними технологіями для задоволення потреб власної самоосвіти, самореалізації) [9].

Слід урахувати, що Нова українська школа будується на основі використання інноваційних методик та інструментів впливу на розвиток, навчання та виховання учнів. Передбачається побудова сучасного освітнього середовища, яке забезпечить необхідні умови, засоби і технології для навчання учнів. Так, зокрема, наскрізне застосування інформаційно-комунікаційних технологій має охопити усі види освітньої діяльності та суттєво розширить можливості, зокрема, у формуванні самоосвітньої компетентності учнів [1].

Таким чином, вивчення існуючих підходів до визначення поняття «самоосвітня компетентність» та встановлення іiі структури засвідчує необхідність їх оновлення в умовах упровадження в освітній процес сучасних цифрових інструментів для побудови інноваційного освітнього середовища.

\section{Список використаних джерел:}

1. Нова українська школа: концептуальні засади реформування середньої школи. URL: https://mon.gov.ua/storage/app/media/zagalna\%20serednya/ nova-ukrainska-shkola-compressed.pdf (дата звернення 09.10.2021)

2. Державний стандарт базової середньої освіти. URL: https://www.kmu.gov. ua/npas/pro-deyaki-pitannya-derzhavnih-standartiv-povnoyi-zagalnoyiserednoyi-osviti-i300920-898 (дата звернення 09.10.2021)

3. Коваленко Н. В. Формування самоосвітньої компетентності учнів основної школи сільської місцевості : автореф. дис. ... канд. пед. наук : 13.00.09. Київ, 2009.

4. Організація самовиховання особистості: навч.-метод. посіб. для педагогів (матеріали авторської творчої майстерні). URL: http://loippo.lviv.ua/ files/2020_2021_nav_rik/tvorchi\%20maysterni/tvorchi\%20maysterni $\% 20$ $2020 / \% \mathrm{D} 1 \% 81 \% \mathrm{D} 0 \% \mathrm{~B} 0 \% \mathrm{D} 0 \% \mathrm{BC} \% \mathrm{D} 0 \% \mathrm{BE} \% \mathrm{D} 0 \% \mathrm{~B} 2 \% \mathrm{D0} \% \mathrm{~B} 8 \% \mathrm{D} 1 \% 85$ $\% \mathrm{D} 0 \% \mathrm{BE} \% \mathrm{D} 0 \% \mathrm{~B} 2 \% \mathrm{D} 0 \% \mathrm{~B} 0 \% \mathrm{D} 0 \% \mathrm{BD} \% \mathrm{D} 0 \% \mathrm{BD} \% \mathrm{D} 1 \% 8 \mathrm{~F} \% 20 \% \mathrm{D} 0 \% \mathrm{BE}$ $\% \mathrm{D} 1 \% 81 \% \mathrm{D} 0 \% \mathrm{BE} \% \mathrm{D} 0 \% \mathrm{~B} 1 \% \mathrm{D} 0 \% \mathrm{~B} 8 \% \mathrm{D} 1 \% 81 \% \mathrm{D} 1 \% 82 \% \mathrm{D} 0 \% \mathrm{BE} \% \mathrm{D} 1 \%$ $81 \% \mathrm{D} 1 \% 82 \% \mathrm{D} 1 \% 96 . \% 20 \% \mathrm{D} 0 \% \mathrm{~A} 7.1 . . p d f$ (дата звернення 09.10.2021)

5. Формування самоосвітньої компетентності учнів - один з найважливіших факторів успішного навчання. URL: https://vseosvita.ua/library/ formuvanna-samoosvitnoi-kompetentnosti-ucniv-odin-z-najvazlivisihfaktoriv-uspisnogo-navcanna-33320.html (дата звернення 09.10.2021). 
6. Рой С. Д. Самоосвітня компетентність майбутніх вчителів предметів гуманітарного циклу, іï сутність та структура. URL: https:// scienceandeducation.pdpu.edu.ua/doc/2015/JRN_8/26.pdf (дата звернення 09.10.2021).

7. Бухлова Н. В. Сутнісний зміст поняття «самоосвітня компетентність». Наукова скарбниця освіти Донеччини. 2008. № 1. С. 4.

8. Гайда В. Я. Суть самоосвітньої компетентності учнів закладів середньої освіти. Стратегії інноваційного розвитку природничих дисциплін: досвід, проблеми та перспективи : матер. II Всеукр. наук.-практ. конф. (Кропивницький, 21 березня 2019 р). Кропивницький, 2019. С. 23-25.

9. Хворостенко I. Розвиток самоосвітньої компетентності як психологопедагогічна проблема. Нова педагогічна думка, 2013. № 3. С. 137-141. 